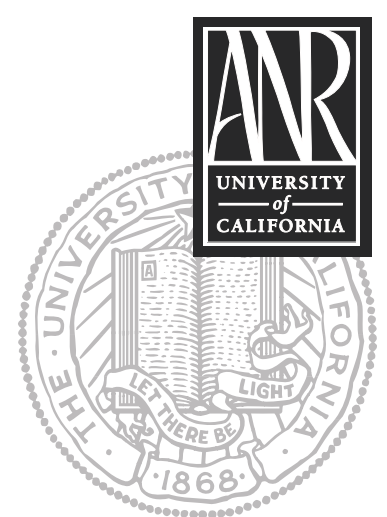

UNIVERSITY OF CALIFORNIA

Division of Agriculture and Natural Resources http://anrcatalog.ucdavis.edu

\title{
Water Quality Treatment for Livestock Feeding and Exercise Areas on California Coastal Dairy Farms and Ranches
}

MICHAEL S. LENNOX, Staff Research Associate, University of California Cooperative Extension, Marin, Sonoma, and Mendocino Counties; DAVID J. LEWIS, Watershed Management Advisor, University of California Cooperative Extension, Marin, Sonoma, and Mendocino Counties; JON GUSTAFSON, State Rangeland Management Specialist, Natural Resources Conservation Service, Davis; KENNETH W. TATE, Rangeland Watershed Specialist, Plant Sciences Department, University of California, Davis; and EDWARD R. ATWILL, Environmental Animal Health and Medical Ecology, School of Veterinary Medicine, University of California, Davis.

\section{INTRODUCTION}

Dairy farms and grazing livestock ranches are integral to the working landscape of California's coast. The landscape, land use history, and livestock distributions of each farm and ranch are unique and constantly changing. Successful farmers and ranchers continuously adapt land use practices to address the challenges of livestock operations, environmental stewardship, and the agriculture economy. Ranch plans integrate these elements to achieve operation viability, including the implementation of management practices that improve water quality (Larson et al. 2005).

Dairy farms and ranches need designated areas for concentrating and handling livestock during certain portions of the year. These areas include exercise lots, sick pens, calving pens, calf corrals, feeding areas, and loafing areas. Together, they represent important production components of dairies and ranches. They contribute to herd health, for example, by providing lactating animals a place to exercise near milking facilities. They also facilitate supplemental feeding in a cost-effective manner. Additionally, when used for nurseries or sick pens, they allow producers to monitor groups of animals that require direct and timely attention. The intensity of traffic within these highuse areas results in bare surfaces where vegetation may be absent or slow to regenerate. This increases the susceptibility of high-use areas to erosion during winter storms, which can result in the delivery of manure and sediment to nearby streams and rivers. The resulting management challenge for high-use areas is to maintain animal productivity, health, and welfare while reducing the impact on water quality.

Producers currently take steps to meet this challenge of caring for both livestock and water quality. Typically, high-use areas are accessed during the drier months of each year. With the onset of winter rains, producers house animals in loafing barns, if available. In addition, they scrape and remove manure from these areas prior to the onset of winter rains. Even with these measures taken, however, high-use areas still have the potential to deliver as much as ten-fold more bacteria, nutrients, and sediment to surface waters in comparison with silage fields and open pasture (Lewis et al. 2005).

To address this potential pollutant delivery and enhance the current on-farm efforts to improve water quality, we have evaluated the benefits to water quality that can be gained from erosion control and revegetation techniques commonly used with construction projects (ABAG 1995). Our specific objective was to implement practices that provide the protective cover needed during winter rains to reduce erosion and transport of manure and sediment. These practices are designed to treat a specific area of concern and include seeding and straw mulching. This publication presents 

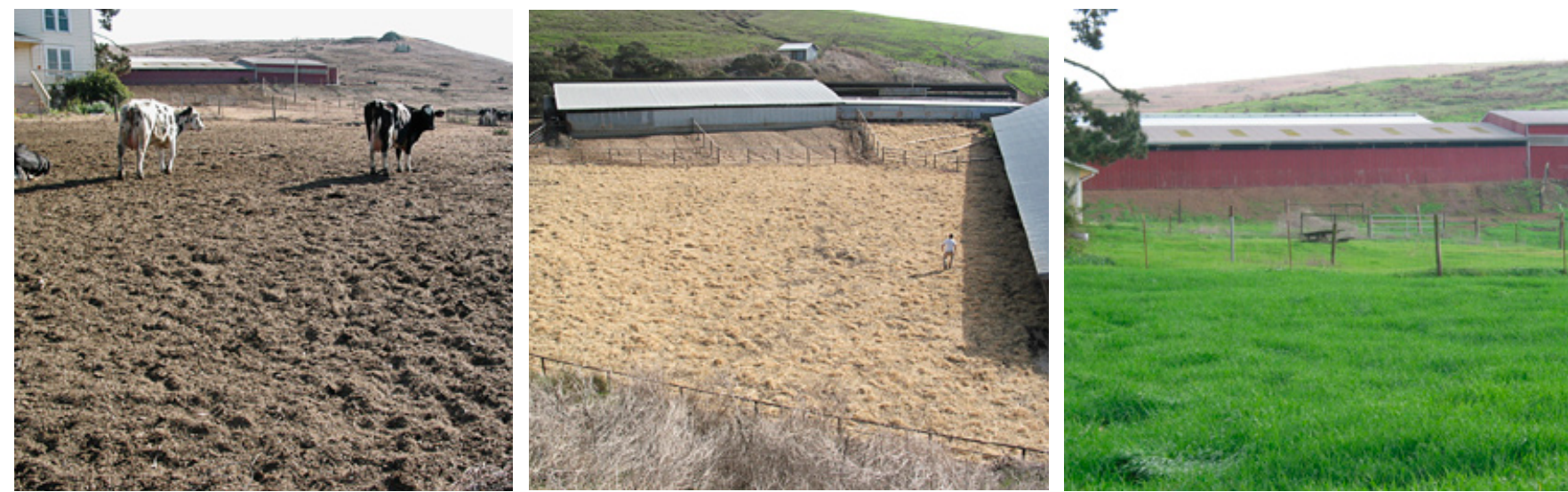

Figure 1. Runoff from high-use areas with exposed soils, like the one on the left, can be a source of sediment, nutrients, and bacteria to nearby streams. Seeding and mulching these sites provides for ground cover by straw (middle), prior to the start of winter rains, and by grass (right) in the winter and early spring. This cover reduces delivery of potential pollutants by improving the quality of water that runs off these high-use areas. Photos: David Lewis and Michael Lennox.

the results of our evaluation, including a summary of the benefits to water quality that these practices generate and suggestions for the installation of these simple, beneficial management practices (BMPs) on a typical coastal farm or ranch (fig. 1).

\section{MANAGEMENT PRACTICE COMPONENTS}

Some areas of intense livestock use are occupied with animals year-round, while others are used only during the drier months from spring to fall. For purposes of our evaluation, we divided these areas into two groups: winter-use and no-winter-use. Livestock are excluded from no-winter-use areas during the winter. By comparison, livestock have occasional to daily access to winter-use areas. This distinction is important because it represents the reality of livestock management in these areas. It also distinguishes the influence that winter-use and no-winter-use each have on the selection and implementation of practices designed to control erosion. In both cases, we worked on Marin and Sonoma County dairies and ranches to compare the benefits of mulching and seeding as an erosion control practice.

We implemented practices that are generally used at construction projects on bare and exposed ground and adapted them to the conditions of coastal dairies and ranches. These practices are designed to prepare sites before the onset of winter storms and the associated potential for erosion and transport of sediment and manure to surface water bodies. A common approach is to combine seeding of annual barley and ryegrasses with a surface application of straw. The straw mulch provides cover during early-winter storms when seeds have not had time to germinate. Once established, the grasses provide ground cover during later winter storms after the straw has decomposed (fig. 2).
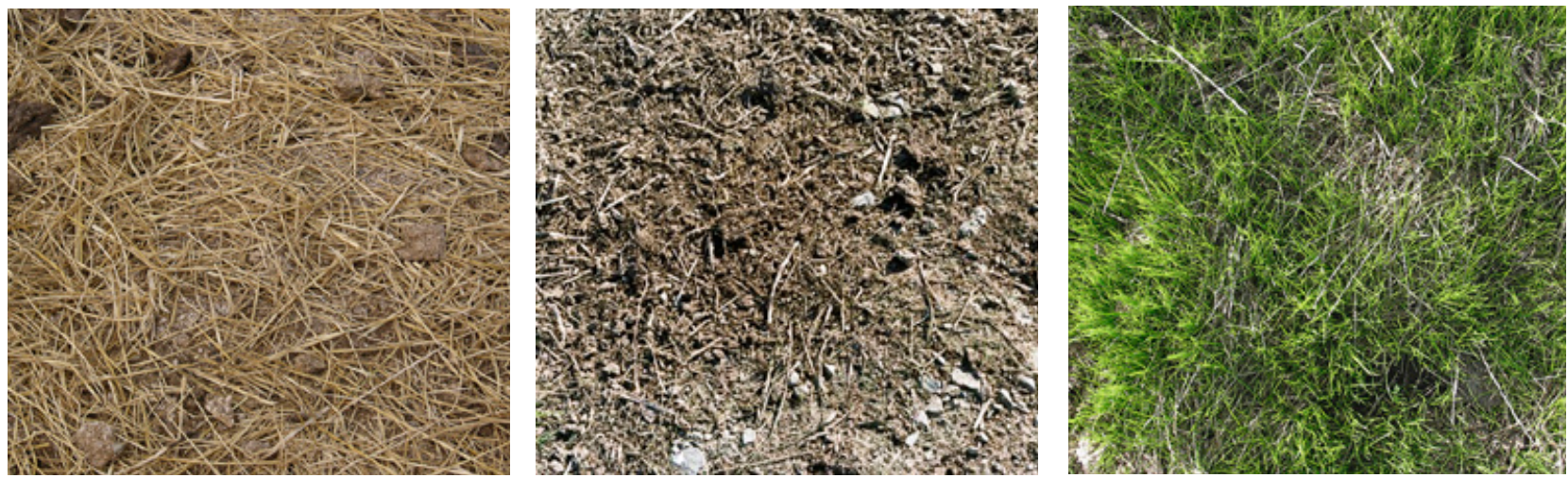

Figure 2. Surface condition of treated areas with recently applied straw (left), 3 months after straw application without seeding (middle), and 1 month after seeding and mulching (right). Photos: David Lewis and Michael Lennox. 
Because many soils in lots or corrals are compacted and marginal, tough and tolerant grass species are needed. Annual barley grass (Hordeum vulgare) comes up fast and strong with early-fall rains, keeping the soil well protected during December precipitation. Annual ryegrass (Lolium multiflorum) takes more time to germinate, but becomes dominant in the late winter and early spring. We recommend mixing the two varieties and observing how they grow on your sites. "Beardless" barley is recommended if livestock will use the forage.

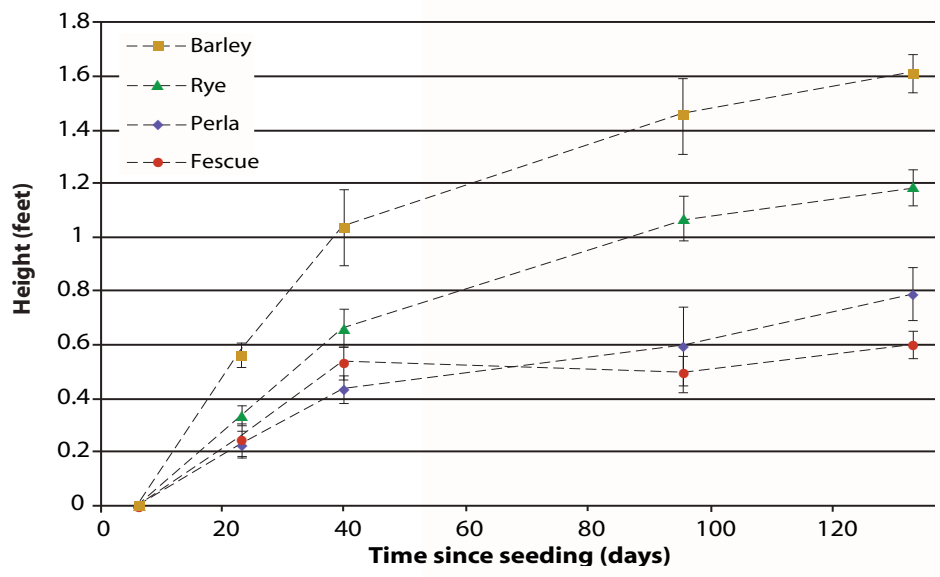

Figure 3. Comparison of mean grass height for selection in treatment of livestock exercise and feeding areas.

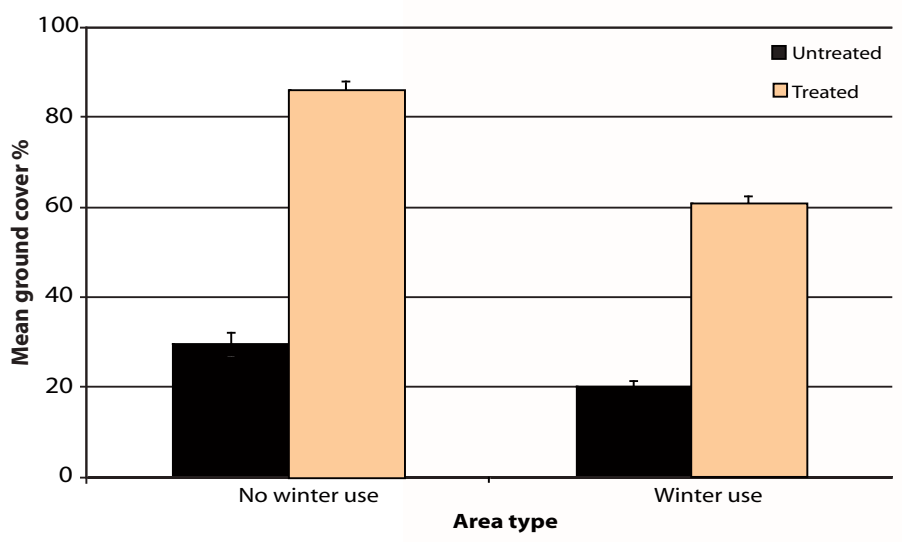

Figure 4: Mean ground cover on untreated and treated exercise and feeding areas.

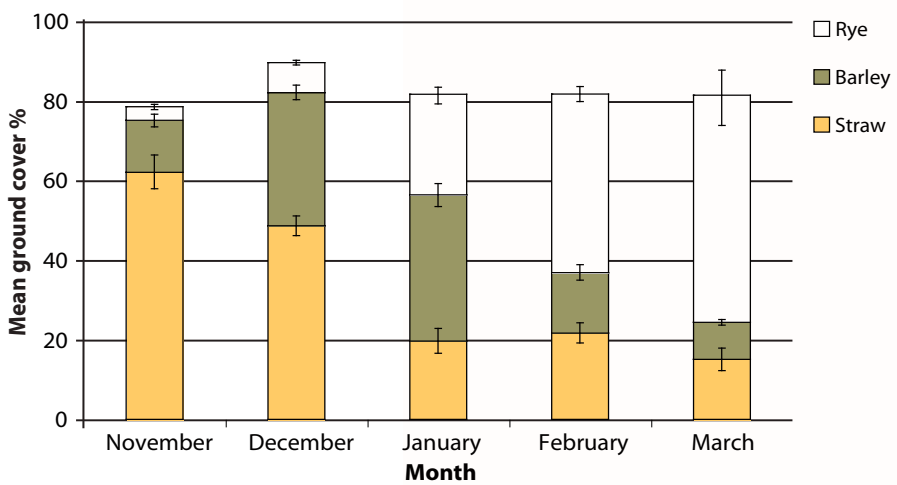

Figure 5: Mean percentage of cover generated by straw mulch, annual barley, and annual rye on treated exercise and feeding areas. In November, straw mulch provided the majority of cover. As it decomposed and the grasses grew, barley contributed a larger percentage of cover in December and January. The rye grew more in February and March, contributing the largest percentage of cover.
To confirm that selected grasses had growth patterns needed to cover these areas, we conducted nursery trials on four grass species (two annuals and two perennials) to measure rates and timing of growth. Annuals used were rye and barley grasses, and selected perennials were tall fescue (Festuca arundinacea) and perla grass (Phalaris spp.). Beware that these perennials can be invasive in coastal areas, and our purpose was to make a comparison between annuals and perennials only. All four species were seeded in 5-gallon containers to control environmental conditions. (For calculating metric equivalents, a conversion table is provided at the end of this publication.) When measured at 23 days after planting, the annual barley was significantly larger than the other grasses and, after 40 days, the annual rye was significantly taller than the perennial grasses (fig. 3). Admittedly, perennial grasses would have different growth rates in successive years but the conditions of our green house study are intended to represent initial conditions of high-use areas after a season of livestock use.

Using field measurements, we evaluated the degree of protection provided by straw and the two annual grasses in winter-use and no-winteruse areas. Estimates of percent ground cover were made once per month from November to March using a step-point method (BLM 1996). The implemented practices were found to provide over 50 percent more cover for no-winter-use areas and 40 percent more cover for winter-use areas than in untreated areas (fig. 4). Cover for untreated winteruse and no-winter-use areas averaged less than 30 percent. By comparison, the combination of mulch, annual barley grass, and annual ryegrass generated 75 percent cover during each of the five months that cover was measured (fig. 5). This amount of cover is maintained over the entire time period as a result of the transition from cover primarily by straw in the early months, followed by barley and rye in the middle months, followed by rye in the latter months. Using only rye to treat these areas is not advised because it will result in low coverage, particularly in the early to middle periods of the winter when the largest storms usually occur. 


\section{WATER QUALITY BENEFITS}

We measured the on-farm effectiveness and water quality improvements attributable to this erosion control practice by comparing treated areas with nearby untreated areas. To do this we used storm-event sampling that included the collection and analysis of surface runoff samples from untreated and treated high-use areas, with and without winter-use. Water samples were analyzed for fecal coliform, total suspended solids, and nutrients including total nitrogen, ammonium, nitrate, total phosphorus, and orthophosphate.

Table 1. Mean concentrations with standard error in parentheses for fecal coliform, total suspended solids, total nitrogen, ammonium, nitrate, total phosphorus, and orthophosphate in surface runoff from treated and untreated winter-use and no-winter-use areas

\begin{tabular}{lrr}
\hline Constituent & Winter-use area & No-winter-use area \\
\hline $\begin{array}{l}\text { Fecal coliform (cfu/100ml) } \\
\text { untreated }\end{array}$ & $1,450,494,250(419.9)$ & $667,971(65.8)$ \\
treated & $4,560,761(308.9)$ & $51,689(9.8)$ \\
Total suspended solids (mg/l) & & \\
$\quad$ untreated & $860.9(4.2)$ & $449.4(3.2)$ \\
treated & $556.1(3.7)$ & $199.7(3.7)$ \\
Total nitrogen (mg/l) & & \\
untreated & $44.2(3.9)$ & $12.9(3.3)$ \\
treated & $16.1(3.4)$ & $8.6(3.0)$ \\
Ammonium (mg/l) & & \\
untreated & $8.9(10.1)$ & $0.6(14.5)$ \\
treated & $1.3(11.0)$ & $0.5(10.6)$ \\
Nitrate (mg/l) & & \\
untreated & $0.7(9.6)$ & $3.4(4.7)$ \\
treated & $2.3(6.8)$ & $3.3(5.0)$ \\
Total phosphorus (mg/l) & & \\
untreated & $19.1(4.9)$ & $9.4(6.0)$ \\
treated & $12.1(5.2)$ & $13.9(1.8)$ \\
Orthophosphate $(\mathrm{mg} / \mathrm{l})$ & & $3.8(3.6)$ \\
untreated & $9.7(2.3)$ & $7.5(3.1)$ \\
treated & $5.9(2.5)$ &
\end{tabular}

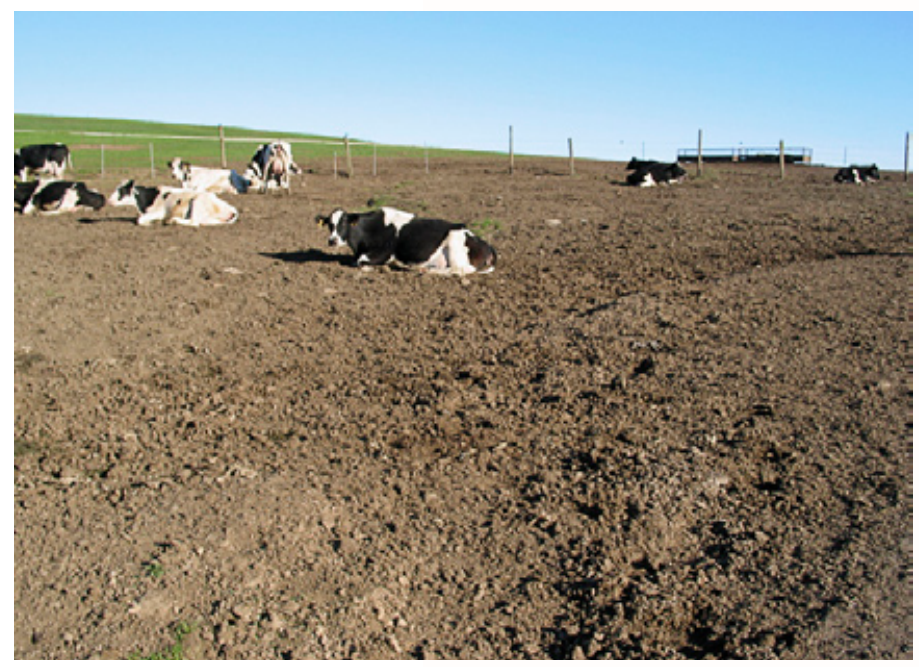

Figure 6 . An exercise and feeding area, like this one, is a good candidate for the proposed mulching and seeding practice. Animals use the area daily in summer months, resulting in little to no cover when rains begin. Winter runoff from the area has the potential to deliver bacteria, nutrients, and sediment to a stream. Photo: David Lewis and Michael Lennox.
Results from our assessment indicate that treated sites show more than a ten-fold reduction in fecal coliform concentrations from runoff when compared with untreated sites (table 1). Results also indicate that concentrations of suspended solids in runoff from treated sites were one-third to one-half less than those from untreated sites. These differences represent a significant reduction in pollutant delivery to receiving waters downstream from high-use areas.

Nutrient results were more mixed, indicating that the treatment interacts with nutrient cycling processes. Nitrogen and phosphorus cycling occurs as the straw mulch decomposes and seeded grasses germinate. This includes the mineralization of nitrogen, making it available for transport in surface runoff.

Pollutant concentrations in runoff from nowinter-use areas were lower than those from winter-use areas. While not feasible and realistic for all operations, these results demonstrate that the combination of mulching and seeding with no-winter-use generates the maximum reduction in surface runoff pollutant concentrations. This combination could be improved further with the addition of a vegetative filter strip to filter runoff (Grismer et al. 2006).

\section{GUIDELINES FOR TREATING AREAS OF CONCERN}

The evaluated practice is relatively easy to adopt and install on coastal ranches and dairies. Following some useful steps and "rules-of-thumb" will help lead to successful treatment application and improvements to water quality. These steps include (1) area identification, (2) the use of proper seeding and mulching techniques, and (3) appropriate timing for practice implementation.

\section{Selection of Priority Sites}

The identification and selection of areas to treat should be directed by the experience and knowledge you have of your dairy and ranch. In general, the proposed mulching and seeding practice is intended for use on those areas (fig. 6) where 
- livestock are concentrated either seasonally or on a year-round basis

- vegetative cover is deficient and incapable of controlling soil erosion

- storm-generated runoff has a connecting drainage path to adjacent ephemeral, intermittent, or perennial streams

Area slope should also be considered, with those of 5 percent or more having a greater potential to generate runoff that can reach area streams.

One convenient method for detecting locations with insufficient vegetative cover is to identify areas that generate fans of soil deposition or erosion following intense rainfall. The best way to confirm the existence of excessive runoff from a poorly vegetated lot or corral is through firsthand observation. Put on the rain gear during a few storms each winter and observe storm-event runoff while it is occurring. Take time to notice whether such runoff connects with adjacent streams.

A word of caution should be made when treating areas above storm grates or culverts. Loose straw and mulch can mobilize and plug these systems, thus backing up water. In these situations, efforts to tack down the mulch or use straw mats are critical (see "Design and Implementation of Treatment" below). Alternatively, seeding but not mulching is a viable way to provide some water quality benefit for the site.

\section{Design and Implementation of Treatment}

Designing and implementing the evaluated treatments can be carried out in a four step process that includes determining area size and materials needed, site preparation, seeding, and mulching with straw.

\section{Determining area size and materials needed}

The first step in designing and implementing this management practice is to measure the size of area to be treated, in square feet or acres, and calculate the quantity of straw and seed to be used. Simply multiply the length by the width of the area to calculate the total area (see "Treatment Calculation Worksheet" below). These dimensions can be figured by pacing them in smaller areas or measuring them on a map for larger areas.

Seeding rates are approximately 100 pounds per acre for annual barley and 25 pounds per acre for annual rye, or a recommended mixture of four parts barley to one part rye. (Use half of the recommended seeding rates for rock dominated soils.) The combined seeding rate translates to one seed per square inch. Calculating the quantity of seed needed for both grasses can be done using the area size calculation (see "Treatment Calculation Worksheet" below). It should be noted that the barley grass does not reseed itself successfully the following year so it will not spread to other areas on the ranch. Thus, the barley needs reseeding each fall while the ryegrass seed will return for years to come. A word of caution about annual ryegrass is that it has the potential to outcompete other grass species. It is fairly widespread on California coastal dairies and ranches. However, if you are concerned about its use on your property you can seed the barley grass alone at a rate of 470 pounds per acre to achieve one seed per square inch. Straw or old hay can be used as mulch; spreading it at rates of one bale per 800 square feet, or 2 tons per acre, provides a good cover (NRCS 2000). "Weed free" straw or hay is preferred if available. 


\section{TREATMENT CALCULATION WORKSHEET}

Area size: Measure and multiply the area's length and width in feet. Then calculate the size in acres.

Length feet $\times$ width feet $=$ area size square feet

Area size square feet $\div 43,560$ square feet per acre $=$ area size acres

Seed quantity: Using the area size calculation in acres, calculate the amount of seed needed for both annual barley and ryegrasses. In general, a four to one mix of barley to ryegrasses works well.

Area size acres $\times 100$ pounds per acre $=$ annual barley pounds

Area size acres $\times 25$ pounds per acre $=$ annual rye pounds

Mulch quantity: Using the area size calculation in either acres or square feet, calculate the amount of straw needed.

Area size acres $\times 2$ tons per acre $=$ mulch tons

Area size square feet $\div 800$ square feet for every bale $=$ mulch bales of straw

\section{Preparing the site}

Prepare the seedbed as well as possible before spreading the seed, particularly where the soil surface is hard and composed primarily of exposed subsoil or gravel and rock base. This preparation supports seed germination. Without it, seeds will not germinate properly and can be washed away by rain. An old-fashioned harrow works well for scratching the soil surface to a depth of about 0.25 inch. Such a harrow can be constructed by using an old piece of fence (chain-link or any narrow gauge) laid flat and dragged around the treatment area with a few weights attached. In addition to harrowing, surface stones that are large and loose should be removed to avoid injury to animals. If left on the surface, they can be covered by the mulch and grass, preventing animals from seeing and avoiding them.

A "sheep's foot roller" can be used following seeding and mulching, as an alternative to preplanting harrow treatment. This is possible if mulch is applied immediately after seeding to prevent seed loss from wind or birds.

\section{Seeding}

Seed should be spread before the straw mulch is applied. Methods for spreading the seed depend on the size of area and type of terrain you will be treating. For example, no-till drills plant seeds quickly in rows; however, rocks may damage the drill, steep sites are not accessible, and it is a waste of time in small areas. A landscaping lawn seeder with a large hopper can be used to rapidly and uniformly seed accessible areas. Hand-held seed spreaders are relatively inexpensive and very mobile for rough or less accessible areas, but they require more time or labor to continually fill the hopper.

\section{Mulching}

Visually inspect the straw or hay for unwelcome weeds prior to mulching. Spreading straw may be done with a pitchfork, spreading fork, or by hand; however, time is money at 5 to 10 minutes per bale (fig. 7). A straw blower is recommended as a cost- 


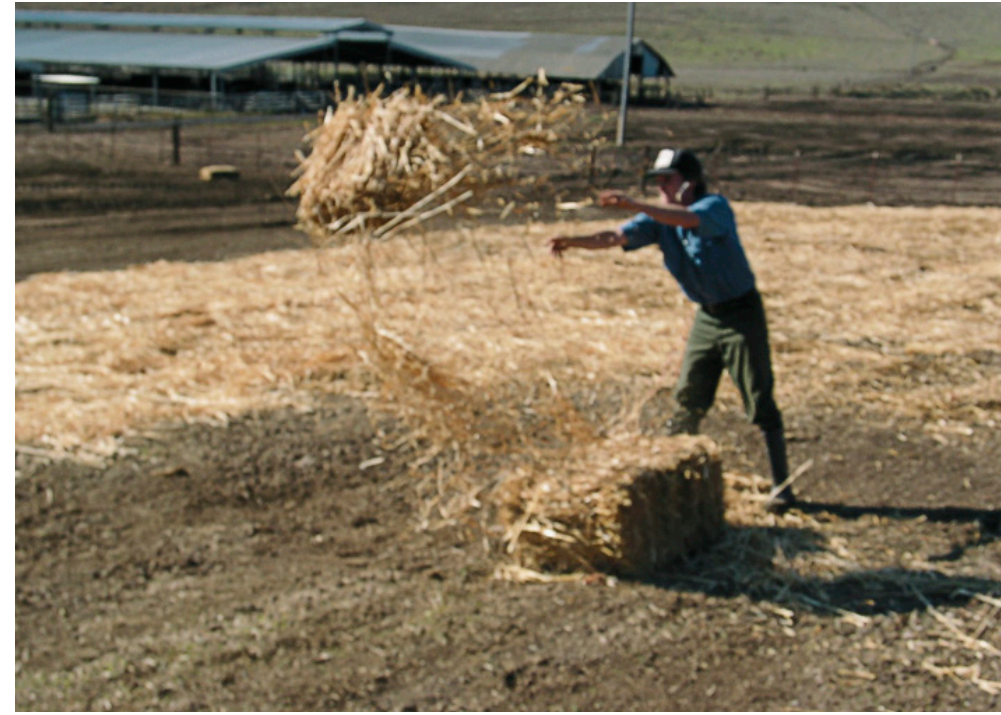

Figure 7. Spreading straw by hand is a possibility for a small area, but to save time on larger areas other options such as blowers are available. Photo: David Lewis and Michael Lennox. effective piece of equipment to quickly cover large areas. They cut and blow the straw to provide uniform coverage, and, as a result, are the most common method used on construction sites. Various sizes of blowers are available through equipment rental suppliers.

The straw mulch should be crimped or tacked to increase contact with the underlying soil. This can be accomplished by hand and shovel on small areas or with a sheep's foot roller for large areas. Crimping can also be achieved by herding livestock over mulched areas.

An alternative method for applying and anchoring straw mulch is to use jute matting or mulch covered with plastic netting, provided livestock will not access these areas during the winter or treatment period. This intensive method is often used on highly erodible construction sites. The advantage is that no crimping is needed because the mats are unrolled down the slope from a small trench. The disadvantages are that material costs are greater and that large staples are needed where mats overlap.

\section{Timing of Treatment Installation}

Dairy and ranch managers in the western states are well aware that climate variation may change ranch priorities and livestock rotations from year to year, and water quality management is no different. The specific timing of treating barren areas depends on when the fall rain arrives. The challenge is that we never know exactly when the rain will begin each fall or how intense it will be. In general, mid-October to early November is an appropriate period for Northern California coastal regions, by which time areas should be seeded and mulched. Keep in mind that the annual barley grass does better the earlier it is planted, taking advantage of the remaining warmer days of fall.

\section{CONCLUSIONS}

The treatment of high use areas on California coastal dairy farms and ranches has been shown to be useful for livestock producers as a tool for improving water quality. The timing and location for implementing these practices on your operation depends on your landscape features, animal rotations, and fall precipitation. In general, high-use areas should be seeded and mulched by late October to mid-November. Realistically, multiple practices such as mulching and seeding in concert with vegetative filter strips are needed in high-use areas in order to address the water quality concerns on your operation. However, the annual combination of seeding and mulching areas of particular water quality concern can significantly reduce potential pollutant delivery downstream. This practice is a useful addition to the ranch manager's "toolbox" for stewardship in twenty-first-century California. 


\begin{tabular}{|c|c|}
\hline \multicolumn{2}{|c|}{ English-metric conversion table } \\
\hline 1 inch & $2.54 \mathrm{~cm}$ \\
\hline 1 square inch & $6.4516 \mathrm{~cm}^{2}$ \\
\hline 1 foot & $0.3048 \mathrm{~m}$ \\
\hline 1 square foot & $0.093 \mathrm{~m}^{2}$ \\
\hline 1 acre & $0.4047 \mathrm{ha}$ \\
\hline 1 pound & $0.454 \mathrm{~kg}$ \\
\hline 1 ton & $0.907 \mathrm{metric}$ ton \\
\hline 1 pound/acre & $1.12 \mathrm{~kg} / \mathrm{ha}$ \\
\hline 1 ton/acre & $2,240 \mathrm{~kg} / \mathrm{ha}$ \\
\hline
\end{tabular}

\section{REFERENCES}

ABAG (Association of Bay Area Governments). 1995. Erosion \& sediment control measures: A comprehensive field guide for controlling soil erosion in California. 2nd ed. Oakland, CA: Association of Bay Area Governments.

BLM (U.S. Department of the Interior Bureau of Land Management). 1996. Sampling vegetation attributes. Interagency technical reference. BLM/RS/ST96/002+1730.

Grismer, M. E., A. T. O'Geen, and D. J. Lewis. 2006. Vegetative filter strips for nonpoint source pollution control in agriculture. Oakland: University of California Division of Agriculture and Natural Resources, Publication 8195.

Larson, S., K. Smith, D. Lewis, J. Harper, and M. George. 2005. Evaluation of California's rangeland water quality education program. Rangeland Ecology and Management 58:514-522.

Lewis, D. J., E. R. Atwill, M. S. Lennox, L. Hou, B. Karle, and K. W. Tate. 2005. Linking on-farm dairy management practices to storm-flow fecal coliform loading for California coastal watersheds. Journal of Environmental Monitoring and Assessment 107:407-425.

NRCS (USDA Natural Resources Conservation Service). 2004. Standards and specifications 342A, USDA-NRCS field office technical guide. Washington, DC: USDA Natural Resources Conservation Service. NRCS Web site, www.nrcs.usda.gov/programs/Env_Assess/EQIP/EQIP_EA_finals/FINAL_BC_ Analysis.pdf.

\section{Acknowledgments}

This work was made possible by Marin Community Foundation, Tomales Bay Agriculture Group, U.C. Sustainable Agriculture Research and Education Program, Western United Dairymen, Marin County Wildlife Advisory Board, and California Sea Grant Extension Program.

\section{FOR FURTHER INFORMATION}

To order or obtain printed ANR publications and other products, visit the ANR Communication Services online catalog at http://anrcatalog.ucdavis.edu. You can also place orders by mail, phone, or FAX, or request a printed catalog of our products from:

University of California

Agriculture and Natural Resources

Communication Services

6701 San Pablo Avenue, 2nd Floor

Oakland, California 94608-1239

Telephone: (800) 994-8849 or (510) 642-2431

FAX: (510) 643-5470

E-mail inquiries: danrcs@ucdavis.edu

An electronic version of this publication is available on the ANR Communication Services Web site at http://anrcatalog.ucdavis.edu.

Publication 8210

ISBN-13: 978-1-60107-437-9

ISBN-10: 1-60107-437-9

(C) 2007 by the Regents of the University of California, Division of Agriculture and Natural Resources. All rights reserved. 
To simplify information, trade names of products have been used. No endorsement of named or illustrated products is intended, nor is criticism implied of similar products that are not mentioned or illustrated.

The University of California prohibits discrimination or harassment of any person on the basis of race, color, national origin, religion, sex, gender identity, pregnancy (including childbirth, and medical conditions related to pregnancy or childbirth), physical or mental disability, medical condition (cancer-related or genetic characteristics), ancestry, marital status, age, sexual orientation, citizenship, or status as a covered veteran (covered veterans are special disabled veterans, recently separated veterans, Vietnam era veterans, or any other veterans who served on active duty during a war or in a campaign or expedition for which a campaign badge has been authorized) in any of its programs or activities. University policy is intended to be consistent with the provisions of applicable State and Federal laws.

Inquiries regarding the University's nondiscrimination policies may be directed to the Affirmative Action/Staff Personnel Services Director, University of California, Agriculture and Natural Resources, 1111 Franklin Street, 6th Floor, Oakland, CA 94607-5201, (510) 987-0096. For a free catalog of other publications, call (800) 994-8849. For help downloading this publication, call (530) 297-4445.

This publication has been anonymously peer reviewed for technical accuracy by University of California scientists and other qualified professionals. This review process was managed by the ANR Associate Editor for Land, Air, and Water Sciences.

pr-3/07-LR/CM 